\title{
Learning from Collaborative Teacher Development in an EAP/ ESP Context
}

\author{
Elena Velikaya \\ National Research University Higher School of Economics \\ Correspondence concerning this article should be addressed to Elena Velikaya, National Research \\ University Higher School of Economics, Malaya Pionerskaya, 12, Moscow, Russian Federation, 115054. \\ E-mail: evelikaya@hse.ru
}

\begin{abstract}
'Collaborative teacher development is an increasingly common kind of teacher development found in a wide range of language teaching contexts'. Teachers can collaborate with other teachers in writing materials, books, doing research, and analysing observed lessons. Even the format and the content of a teaching journal can be developed in cooperation with other colleagues. The article reports on collaborative teacher development of English language teachers at the National Research University Higher School of Economics (NRU HSE) in Moscow, Russia. The study used a survey to investigate needs for teacher development at NRU HSE. Findings reveal that not all teachers practise self-observation; many teachers believe that feedback must be personal; the majority of teachers find peer observation subjective; almost all teachers have teaching journals but their understanding of what a teaching journal is seems to be erroneous. These results indicate that without a clear understanding of the listed above issues and their implementation in a given context professional development can hardly be possible. The author analyses the results of this research and makes suggestions about teacher development as a continuous and collaborative process.
\end{abstract}

Keywords: collaborative teacher development, EAP/ESP, self-observation, peer observation, peer-coaching, teaching journal, professionalism

Teacher development has become an integral part of teachers' professional careers. There is a pressure for teachers to update their knowledge and skills in various areas such as innovations, new trends, course design, technology, assessment, and research, and it is the teaching institution and the classroom which serve as a major source for further development.

Ongoing teacher education in English language teaching circles at the NRU HSE has been given a new focus as a result of the introduction of a new concept of teaching English at the university (HSE, 2010) and new requirements for teacher professional assessment. According to these requirements, continuous professional training is now treated as a basis for a teacher's success in his or her work. The requirement to write research articles and teach optional courses is very topical now since these additional activities demonstrate teacher's active role in both teaching and in professional development. On the other hand, not all that teachers need to know can be provided by the administration of the university, even a very advanced university and other various forms of training. Much in teacher development can be done by teachers themselves in collaboration with other teachers as part of their individual long-term plan to update their knowledge and to make their professional development a continuous process.

Language teachers' high qualification is becoming more and more topical in any teaching context since a demand for employees with good skills is more than one or at least one foreign language is very high on the labour market due to the process of internationalisation of education. As a result, teaching profession is becoming more competitive, and teachers who demonstrate continuous self-development are highly demanded. Not simply teachers who know the subject well, but those who are devoted to professional training and extend their qualification to research and publications in professional journals and teacher magazines, make presentations at international conferences and belong to professional organisations (TESOL, IATEFL, etc.), those who want to become 
'part of a worldwide community of professionals with shared goals, values, discourse, and practices ... with self-critical view of ... own practices ... (Burns \& Richards, 2009, p. 3).

Traditionally, language teacher development has been looked at as attendance of teacher training courses and seminars (inside and outside the university) which offered (luckily for the teacher) 72 hours of training and a certificate of attendance. This has always served as a proof that the knowledge was updated. It is still common practice in many universities in Russia. In the worldwide teaching communities teacher professional development has made a significant step forward: more self-directed, more collaborative, and more inquiry-based forms begin to emerge. They are 'teachers' informal social and professional networks, including their own classrooms', which function as 'powerful sites for professional learning; teacher inquiry seminars, peer coaching, cooperative development, teacher study groups, and critical friends group (Johnson, 2009, p. 25). These forms have developed as a result of teachers' examinations of their own practices and students' learning. The cited authors believe there is correlation between 'teacher professional learning and student learning' (Johnson, 2009, p. 25). The effect is teachers' reconceptualisation of some aspects of their teaching 'when they come to think about and organise activities in the classroom in fundamentally different ways'. There is evidence that critical thinking about own teaching practices 'encourages teacher-learners to critically reflect on their own identities and positioning in society' (Hawkins \& Norton, 2009, p. 34). 'Self-reflection provides a window on the relationship between the individual and the social world, highlighting both constraints on and possibilities for social change' (Hawkins \& Norton, 2009, p. 34).

\section{Data Collection}

In order to understand how critically English language teachers of the HSE think about their own teaching methods and practices and the importance of changes to their understanding of certain professional development issues a survey was conducted. A questionnaire containing six questions (five - open questions and one - closed question) was prepared. All questions required teachers' answers about the importance of self- and peer observation and keeping teaching journals in professional development. These were the questions asked:

1. Have you ever practised self-observation? If yes, do you think it can help in teacher development?

2. How can feedback on peer observation be orgaised in a tactful way?

3. Can judgements about peer observation be subjective?

4. What can be the criteria for a teacher's assessment in peer observation?

5. How important are peer observation and peer coaching?

6. How can keeping a teaching journal add to a teacher's success in the classroom and professional career?

Data collection was performed using opportunity sampling method (Rogers \& Willoughby, 2013, p. 53). 12 teachers who volunteered to participate in the study were asked to fill in the questionnaire. All teachers were of the same cultural background and approximately the same age. Out of 12 teachers only four knew what self-observation is, and they admitted that they practise it in the classroom because it allows teachers to critically analyse their teaching methods and the teaching process as a whole. One respondent answered that she does it on a regular basis when she analyses her classes, her own successes and failures. Two teachers answered that they tried it but failed because it is difficult to be objective to yourself, and to have some other person's opinion would be more reasonable and fairer. Five teachers confessed they had never conducted self-observation.

Answering the second question, the teachers had three different views: (1) five respondents thought that peer observation must be transparent. Moreover, teachers must know much in advance that their classes will be observed in order to prepare properly. They also believe that feedback ought to be organised in a friendly way on the basis of principles of pedagogical ethics. (2) Six respondents stated that the feedback should be personal and not accessible to a wide audience. (3) Only one respondent doubted that it can be useful in any way because professional approach can be substituted by good personal relationship.

Ten teachers thought that judgements about peer observation (3d question) are always subjective, and the reason for this is again personal relationship. Only two respondents believed that they ought to be objective and demonstrate the observer's professionalism. In response to Question 4, almost all teachers put the criterion of knowledge of the subject in the $1^{\text {st }}$ place. The second important criterion for them is appropriateness of teaching methods. Some teachers added to it good and logical planning of the lesson and the skill to explain and contact with the audience. The third important criterion is satisfaction of the students. A few teachers included such criteria as a skill to motivate students and self-discipline and self-control.

In answering the $5^{\text {th }}$ question, all teachers agreed that peer observation and peer coaching are essential for professional development, but some of them decided they are more important for beginner teachers and newcomers. There were respondents who believed 
that experienced teachers could also benefit from both.

The last question caused a shock with only one teacher who answered that she does not have any idea of what a teaching journal is. The other 11 teachers thought that keeping it is useful because it helps to assess strong and weak points of teaching activity, record failures and successes. Three out of 11 teachers thought it helps in time management and selfdiscipline and self-reflection. One teacher answered that keeping a teaching journal can seriously add to a teacher's success, and another teacher was sure that it enables teachers to make comparative analysis of their work and seek ways of professional development on a regular basis. From all these answers, it is not very clear though how much of what teachers agree on they practise in the classroom. Results of this experiment are given in Figures 1-4.

Teacher development means many different things to different people. Tomlinson (2003) suggests that in a teacher development approach teachers 'are given new experiences to reflect and learn from' (in Harmer, 2013, p. 410). The author believes that the best of these tools is to involve teachers in writing teaching materials since when they do it they have to think carefully about what they want to do, why they want to do it and how to make it happen (in Harmer, 2013, p. 410). It is obvious that writing teaching materials is important for teacher development, but it is also clear to teachers that the analysis of individual teaching practices is even more important. Several teachers,

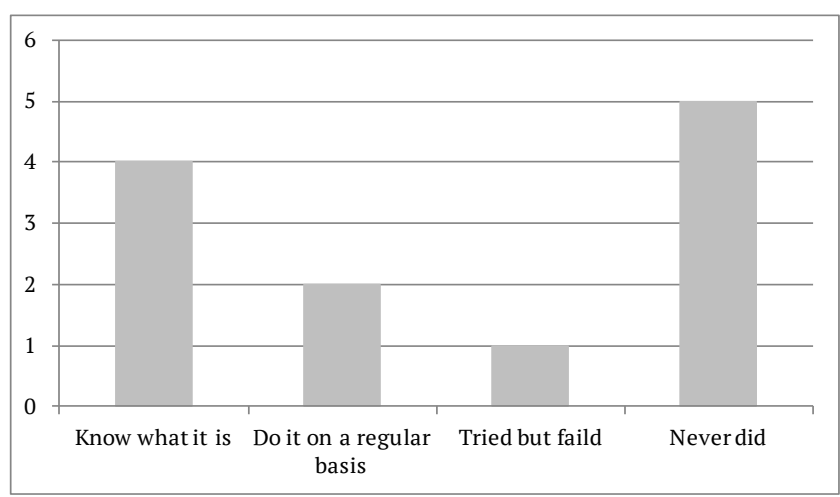

Figure 1. Self-observation.

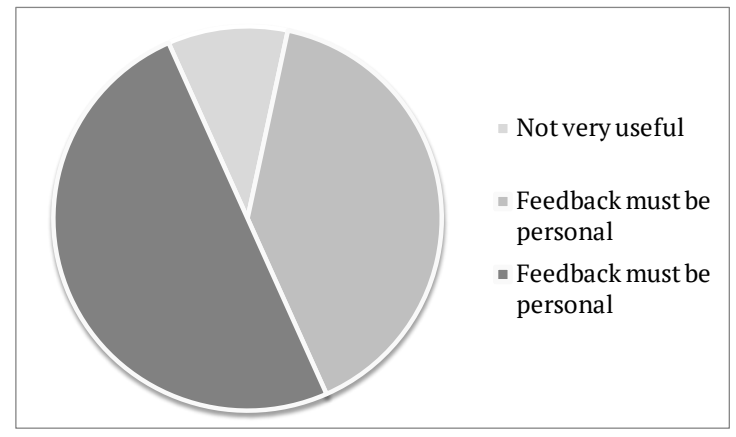

Figure 2. Feedback. who participated in this research, answered that they practise self-observation in the classroom, but they did not mention that they understand what selfobservation in worldwide teaching practices means. In fact, it means 'recording ourselves' (in Harmer, 2013, p. 412), which no teacher reported doing.

\section{Suggestions on Continuous and Collaborative Teacher Development. Self-Observation}

If teaching is looked at by teachers as a careerlong process, an analysis of their teaching practices and beliefs and teacher development goals ought to be conducted. How can, for example, self-observation help teachers in building up their careers? Some authors (Baily, Curtis, Nunan, Fanselow, Gebhard, Oprandy as cited in Burns \& Richards, 2009, p. 252) call it 'non-judgemental observation' which can include 'asking teacher-learners to record their teaching, listen to or view the tape as they collect descriptions of classroom interaction'. These descriptions can then be studied, discussed, and used as case studies for learning with other teachers (Burns \& Richards, 2009 , p. 252). Templer (2004) suggests that that very simple recording equipment can be used because the purpose of the recording is to lead teachers to reflect on what happened and perhaps cause them to think of how they might do things differently in the future. This reflection can be conducted in various forms:

1. Asking yourself questions (Have I done well in the classroom?, Were my reactions good?, Have

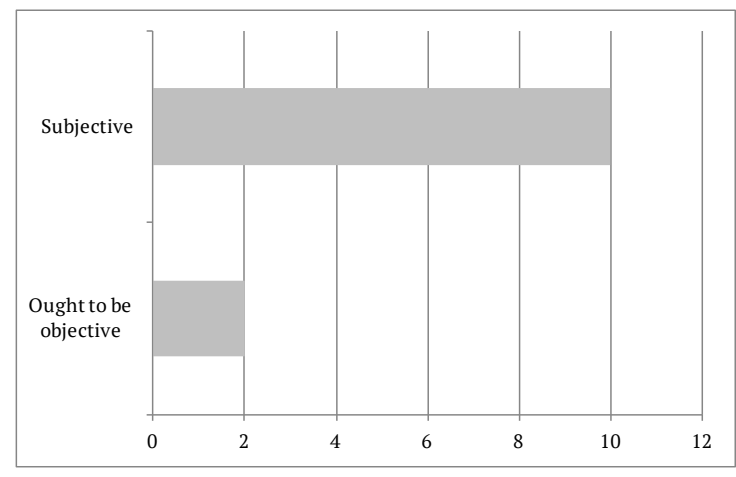

Figure 3. Judgements about peer observation.

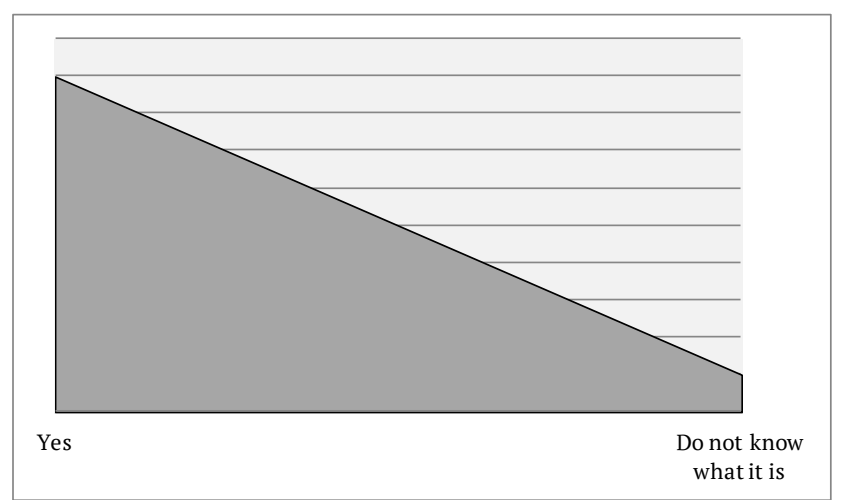

Figure 4. Teaching journals. 
I achieved the goal?, What can I change?, What other techniques can I use to achieve the goal?, etc.).

2. Interpreting your own behavior in the classroom from the point of view of 'what I do and what I think I do' (Rolf Tynan cited in Harmer, 2013, p. 413).

The most widely used approaches to selfobservation of language lessons are: lesson reports, audio-recording a lesson, and video-recording a lesson. Self-observation is meant for the good of the teachers, and it can serve as evidence for making decisions about a teacher's strengths and weaknesses and working out recommendations on how and what to change in his or her teaching. The major advantage of self-monitoring is that it usually gives an objective account of one's teaching which can be different from his or her own perception. For example, teachers are not allowed to use native language at the lessons even in low groups. But many teachers are unaware of the fact that they sometimes do it quite unconsciously. Teacher dominating in the classroom is common, and it can be only eradicated if teachers analyse the recording in, for example, a teacher support group and with a supervisor. Teachers' reactions to using mobile phones by students in the classroom would be better understood as a thing which was not very successful when it was recorded. Many teachers have no difficulties in explaining various issues to students, but teachers who are used to teaching advanced students will probably feel uncomfortable in a classroom with low-level students and vice versa.

The results of self-observation in general can be summarised in a self-report in which the teacher could analyse the advantages and the disadvantages of the lesson self-monitored and also whether the preplanned activities went in the right direction, how he or she managed the discipline and the unexpected. Video- or audio recording is a private issue, and the teacher may not share the self-report with the colleagues or supervisor, but for the sake of teacher development this evaluation can be invaluable. Other teachers can learn from the video- or audio recording how to plan and structure their lessons, how to explain new material and brainstorm ideas, how to correct mistakes and give feedback. The way how the teacher dresses and behaves in the classroom can also identify problems. It is very probable that with time and experience teachers will get used to videotaping and will get less stressed and the whole of the lesson will be more educational and beneficial. Besides, if the teacher repeats videotaping several times during the academic year, he or she will see both students' and self-progress. It will also develop the teacher's sense of confidence and self-esteem and identify areas of improvement, and can be included as a component of the teaching portfolio.
How can HSE teacher be motivated to observe themselves in the right way? Only as a result of collaborative teacher development when issues of self-reflection are analysed in teacher groups and, probably, compared with other teachers' results. This experience can add not only to self-development but to other teachers' development and uncover views of classroom behavior which usually remain unnoticed or even neglected but in the long-run can serve as an investment into teachers' professional careers.

\section{Peer Observation}

Self-observation can hardly be successful without well organised peer observation. Peer observation basically means observing another teacher's classroom and reflection on the advantages of it for both teachers. It is very common that younger teachers can benefit from peer observation conducted by a more experienced teacher, but if it is organised on a mutual basis with the purpose of professional development, even experienced teachers can learn from each other. Peer observation is in fact seeing 'one's own teaching differently' (Fanselow, 1988, p. 115). In this case teachers can 'construct and reconstruct, and revise (their) own teaching' (Fanselow, 1988, p. 116). 'It provides an opportunity for the teacher to see how someone else deals with many of the same problems teachers face on a daily basis.

The majority of interrogated HSE teachers of English expect that peer observation will be subjective. To a large extent it is true, but if it comes from a 'critical friend (Harmer, 2013, p. 419) with interest and for mutual development, then it can be very useful. For example, a teacher might discover that a colleague has 'effective strategies that the observer has never tried' (Richards \& Farrell, 2005, p. 86). The information obtained by the observer can include a written account (in the form of a narrative), a brief description of key events ('field notes'), and a structured inventory listing features of a lesson ('a checklist') that the observer completes during observation (Richards \& Farrell, 2005, p. 89).

What should the observer focus on during observation? The authors of the cited above book suggest the following dimensions:

1. How the teacher starts and ends the lesson.

2. How the teacher allots time within the lesson.

3. How the teacher assigns tasks within the lesson.

4. How the teacher deals with a reticent student.

5. How the teacher organises learning groups.

6. How the teacher supervises students while they are learning.

7. How the teacher asks questions.

(Richards \& Farrell, 2005, p. 90)

One more benefit of peer observation which cannot be underestimated: its social value. It gives 
an opportunity to share ideas, discuss problems and concerns in this way building collegiality at the university.

These findings are slightly different from factors which are taken into consideration by the university committee when a teacher goes through a contest to prove his or her qualification (once in three years). The Head of the Department of Foreign Languages E. Solovova believes that the observer in this case has a right to obtain from the teacher a plan of the lesson (E. Solovova, personal communication, 2015, October). While observing the lesson, he or she must focus on the aim and content of the lesson and decide whether they are topical, reasonable and go with the Concept of teaching English at the HSE. The observer will also be interested in the manner of teaching (academic or not), the atmosphere in the classroom, and whether the teacher's language skills are high. One factor which cannot be overlooked by the observer is teacher's instructions to the students (clear or not, relevant or not, logical or not) and a variety of forms of class work: individual or in twos and threes. If streaming was not initially used to group students, then the teacher must provide higher level students with more difficult tasks. The teacher's manner of error correction and giving feedback is taken into account by the observer. At least for one teacher in 2015 the lack of this determinant was decisive in making a decision about extending the contract for next year. Needless to say that the teacher must be familiar with all technical means of the optimisation of the teaching process and use LMS (Learning Management System) which is similar to Moodle (Solovova, personal communication, 2015, September).

\section{Peer Coaching}

Peer observation can also serve as a basis for peer coaching. In the real sense of the word this notion is almost unfamiliar to the given context. Teachers can collaborate about some teaching issues, exchange ideas, ask for advice, but it is never done on a regular and official basis. Robbins states that peer coaching is 'a confidential process through which two or more professional colleagues work together to reflect on current practices, expand, refine, and build new skills, share ideas; teach one another; conduct classroom research; or solve problems in the workplace' (1991, p. 1). This kind of collaboration is supposed to be positive and supportive in order to provide feedback and suggestions to the other teacher. Richards and Farrell (2005) list the following forms of peer coaching:

1. a series of informal conversations about what is happening in the teacher's classroom;

2. a collaboration on preparation of teaching materials;

3. observation of each other's classes;

4. co-teaching lessons;

5. videotaping a lesson with subsequent discussion with a coach.

(Richards \& Farrell, 2005, n.p.)

Benedetti (1997) lists three types of peer coaching: technical coaching, collegial coaching, and challenge coaching (p. 41). According to this author, technical coaching is revealed when a teacher needs assistance of a more experienced teacher in learning a new teaching method or technique; collegial coaching focuses on improving existing teaching practices; challenge coaching means collegial resolving problems in teaching. All the listed types work well in various contexts where there is a need to implement them. What is required is open-mindedness of the teacher and professionalism of the coach. In any type of peer coaching, there ought to be friendly and constructive feedback which will help the younger or less experienced teachers to develop knowledge and skills needed to teach the subject. Peer coaching will be even more fruitful if the feedback and experience obtained is discussed in larger teacher support groups or even at teachers' meetings on a regular basis. More experienced teachers must be encouraged to be coaches with a reduction of hours taught at the university, and coaches must expect that they will have to produce feedback to the supervisor or the Head of Department containing their report on how the coaching went on and their deductions on the results obtained. Alternatively, it can be done in the form of a questionnaire prepared by the supervisor.

\section{Keeping a Teaching Journal}

Almost all teachers keep a record of their students' results in the form of marks for particular activities and exams. It helps teachers to work out the students' final result. This is obviously the way the interrogated teachers of English at the HSE understand the meaning of a teaching journal. Meanwhile teachers who are acquainted with methodological books written by well known authors realise that a teaching journal is 'an ongoing written account of observations, reflections, and other thoughts about teaching, usually in the form of a notebook, book, or electronic mode, which serves as a source of discussion, reflection, or evaluation' (Richards \& Farrell, 2005, n.p.). It can include teachers' thoughts about their teaching and their students, 'teaching beliefs and practices, as well as a record of self-observations and observations in their classrooms, conversations, teaching ideas, teaching questions and answers, and personal thoughts about developing a teacher identity' (Gebhard, 2009, p. 253). In this format the notion of a teaching journal 
is unfamiliar to the majority of language teachers in the given context. It is very probable that some teachers (quite advanced in ideas and not indifferent) ask themselves such questions as 'What have my students learnt today?', 'Were the teaching methods appropriate?', 'Have they obtained the required skills?' Some of the teachers might summarise the content of the lesson and even ask students what they have learnt at the lesson. But almost no teacher will keep a record of all of these events because they were never told to do so by the supervisor or they were never explained that it is common practice in other countries.

What seem to be the advantages of keeping a teaching journal? There are at least two mentioned in Richards \& Farrell (2005) - to serve as a recollection of what happened during the lesson (successful and unsuccessful experience) and as a source for further learning. Such teaching journals can be read individually or shared with other teachers, which can add to collaborating with colleagues and, as a result, to professional growth and development. Making teachers keep a teaching journal and making it an integral part of their personal and professional development can be rather difficult because now some teachers resist even having a teaching portfolio, which they call 'unnecessary paperwork'. Under these circumstances, making a teaching journal part of a teaching portfolio would show teachers of English what it means to be part of the worldwide teaching community, too.

\section{Teacher Development and Professionalism}

It is a well known fact that 'the teacher is the ultimate key to educational change and school improvement' (Hargreaves \& Fullan, 1992, p. ix). This means that teachers very often develop the English language programme, implement it in the classroom, make amendments to it if necessary, design the English language course, adjust it to a particular group of students, develop materials for it and learn from these activities developing certain skills. Does this result in their professional development? Ur (2013), for example, defines a professional both in a broad and a narrow sense. In the broad sense a professional is 'someone whose work involves performing a certain function with some degree of expertise (p. 388). According to her narrower definition, 'professionals are people such as doctors, teachers and lawyers, whose expertise involves not only skill and knowledge but also the exercise of highly sophisticated judgement and whose accreditation necessitates extensive study'. Claiming that English teachers are professionals since they are a community, they are committed, they publish and communicate their ideas, they learn continually, they are autonomous and they are responsible for training new teachers, Ur, nevertheless, questions whether English teaching "has reached the level of professionalism that seems desirable because there are still many amateurs who think that if they know English, they can teach it (Ur, 2013, pp. 391-392). This can be true for any environment: there will always be people (not professional teachers) who would like to supplement their income by giving private lessons to beginners or school children. But in Russia, no one can be employed as a teacher of English (school or university) without pedagogical education obtained at a university or teacher training college. With pedagogical education of this kind, English teachers become real professionals if they not only teach English and not one course only (for instance, Business English) but if they constantly develop, communicate with teachers worldwide, learn from them and share their own experience at international conferences. Becoming a collaborative teacher is an important step in being more professional in what teachers do in the classroom.

\section{Conclusion}

Teachers are generally motivated to continue their professional development, and for many teachers their education is a process which takes place over time. Since all teachers have a different level of knowledge, experience, and skills, mutual sharing of knowledge and experience becomes a valuable source of professional growth. As it has been explained on the example of one particular teaching context in this paper, such tools in teacher development as self-and peer observation and peer coaching, which are new for EAP/ESP teachers at the NRU HSE, can help them to better understand their own and other teachers' practices and can also help to teach one another and develop new skills. Having a teaching journal can serve as a means of keeping a record of self-observation and other observations in a classroom, of teaching ideas, and personal thoughts about professional development. In the $21^{\text {st }}$ century teacher development with the help of many of the above listed powerful ideas can become less isolating and more collaborative and concentrated on particular teachers' needs with a focus on a much higher level of professionalism.

\section{References}

Benedetti, T. (1997). Enhancing teaching and teacher education with peer coaching. TESOL Journal, 7(1), 41-42.

Burns, A., \& Richards, J. C. (Eds.). (2009). The Cambridge 
guide to second language teacher education. Cambridge, UK: Cambridge University Press.

Department of Foreign Languages, Higher School of Economics. (2010). The concept of English language teaching at the HSE. Bachelor level. Moscow, Russia: HSE.

Fanselow, J. F. (1990). "Let's see": Contrasting conversations about teaching. In J. C. Richards \& D. Nunan (Eds.), Second language teacher education (pp. 182-199). Cambridge, UK: Cambridge University Press.

Gebhard, J. G. (2009). The practicum. In A. Burns \& J. C. Richards (Eds.), The Cambridge guide to second language teacher education (pp. 250-258). Cambridge, UK: Cambridge University Press.

Hargreaves, A., \& Fullan, M. G. (1992). Understanding teacher development. New York, NY: Teacher College Press.

Harmer, J. (2013). The practice of English language teaching. Harlow, UK: Pearson Education Limited.

Hawkins, M., \& Norton, B. (2009). Critical language teacher education. In A. Burns \& J. C. Richards (Eds.), The Cambridge guide to second language teacher education (pp. 30-39). Cambridge, UK: Cambridge University Press.

Johnson, K. E. (2009). Trends in second language teacher education. In A. Burns \& J. C. Richards
(Eds.), The Cambridge guide to second language teacher education (pp. 20-29). Cambridge, UK: Cambridge University Press.

Johnston,B.(2009). Collaborative teacher development. In A. Burns \& J. C. Richards (Eds.), The Cambridge guide to second language teacher education (pp. 241249). Cambridge, UK: Cambridge University Press.

Richards, J. C., \& Farrell, T. S. C. (2005). Professional development for language teachers. Cambridge, UK: Cambridge University Press.

Robbins, P. (1991). How to plan and implement a peer coaching programme. Alexandria, VA: Association for Supervision Curriculum Development.

Rogers, L., \& Willoughby, D. (2013). Numbers. Data and statistics for the non-specialist. London, UK: HarperCollins Publishers.

Templer, B. (2004). Reflective teaching in the lowresource classroom: Reinventing ourselves as teachers through self-scrutinity. Humanising Language Teaching, 6(3). Retrieved from http:// www.hltmag.co.uk/sept04/mart3.htm

Ur, P. (2013). The English teacher as professional. In J. C. Richards \& W. A. Renandya (Eds.), Methodology in language teaching. An anthology of current practice (pp. 388-392). Cambridge, UK: Cambridge University Press. 